\title{
STRENGTHENING THE BILL OF RIGHTS
}

\author{
Andrew S Butler*
}

This article was presented as a Victoria University of Wellington Centennial Lecture during Law Festival week in 1999. The author critically examines two aspects of the current operational structure of the New Zealand Bill of Rights Act 1990 - the subordination of the Bill of Rights to all enactments (section 4) and the issue of "positive vets" of proposed legislation by the AttorneyGeneral (section 7). The author identifies them as weaknesses, and makes suggestions as to possible improvements.

\section{INTRODUCTION}

Ladies and gentlemen, when the New Zealand Bill of Rights Act 1990 (the Bill of Rights) was enacted in late 1990, the general perception of it among the public and the legal profession was that it was a measure of no significance. ${ }^{1}$ The atmosphere of the time was well captured by the as-ever perceptive cartooning of Tom Scott. In a contemporaneous 1990 issue of "The Dominion", Scott depicts a mangy and bewildered dog, who clearly would not hurt a flea, at the end of a long leash held by Geoffrey Palmer (who had been the prime instigator behind the Bill of Rights and was then Prime Minister) who is loudly declaiming "Stand back everyone! One false move and you'll get a limb torn off!". ${ }^{2}$

* Senior Lecturer, Faculty of Law, Victoria University of Wellington (on leave July 1999-December 2000); Crown Counsel, Crown Law Office, Wellington (since May 1999). The views expressed in this paper are entirely personal and should not be regarded in any way as reflecting the views of the Crown Law Office.

1 See generally P Rishworth "The Birth and Rebirth of the Bill of Rights" in G Huscroft \& P Rishworth (eds) Rights and Freedoms (Brookers, Wellington, 1995) 25.

2 The cartoon is reproduced in M Chen \& G Palmer Public Law in New Zealand: Cases, Materials, Commentary and Questions (Oxford University Press, Auckland, 1993) 465. [A copy was shown to the audience.] 
Of course, as Geoffrey certainly knew, but Tom Scott perhaps did not, there was across the road from Parliament a rather excellent set of kennels on Molesworth Street! ${ }^{3}$ As most of us will be aware, since the enactment of the Bill of Rights, the courts led by the Court of Appeal have breathed life into a constitutional document which many had erroneously assumed to be without clout. Looking back now almost nine years after the passage of the Bill of Rights, and notwithstanding the recent vagaries and vicissitudes of the Court of Appeal's jurisprudence in respect of the criminal rights, ${ }^{4}$ the Bill of Rights can be justly seen as having been a significant constitutional development. ${ }^{5}$

However, there are a number of structural weaknesses in the Bill of Rights which significantly impair its efficiency and give rise to substantial operational difficulties. ${ }^{6} \mathrm{My}$ purpose in this lecture is to consider whether there are ways in which the structure of our Bill of Rights can be strengthened in order to better give effect to its twin purposes, yet in a manner which is compatible with the current political reality that favours the retention of parliamentary sovereignty. Due to time constraints I will concentrate on two aspects.

First, I propose that we take a hard look at section 4 of the Bill of Rights and abandon it. It will be recalled that this is the section which is regarded as protecting parliamentary sovereignty. It is addressed explicitly to the courts and prevents them from invalidating, disapplying or impliedly repealing a provision (or provisions) of any other enactment merely on the ground that that provision (or those provisions) is (or are) inconsistent with the rights and freedoms guaranteed by the Bill of Rights. In my view, we would be much better served with a scheme similar to that which appears in the Canadian Charter of Rights and Freedoms 1982. (Along the way, we will consider, and I will reject, the model found in the United Kingdom's Human Rights Act 1998.) Under the Canadian Charter, the courts have a general power to strike down legislation which is inconsistent with the rights and freedoms guaranteed by the Charter, but in terms of section 33 of the Charter the federal and provincial parliaments retain the ability by a simple majority to override (almost all) Charter rights and freedoms through the simple expedient of stating in the

3 The New Zealand Court of Appeal is located on the corner of Molesworth and Aitken Sts in Wellington.

4 See A S Butler "The End of Principle and Precedent in Bill of Rights Cases? A note on R v Grayson" [1997] NZ Law Review 274; H Schwartz "The Short Happy Life and Tragic Death of the New Zealand Bill of Rights" [1998] NZ Law Review 259; S Optican "Search and Seizure in the Court of Appeal - An Essay on the Uses and Misuses of Section 21 of the Bill of Rights" (1999) 18 NZULR 411.

5 See to similar effect P Rishworth "Human Rights" [1996] NZ Law Review 298, 299.

6 There are other potential deficiencies in the Bill of Rights which I will not cover here, such as the absence of certain rights like good name, property, aboriginal rights, and so on. 
relevant legislation that the legislation is to operate notwithstanding that it is inconsistent with the Charter.

Second, I suggest that the section 7 vetting process needs revisiting. It will be recalled that under section 7 of the Bill of Rights the Attorney-General is required to report to Parliament where a Bill (whether a Government Bill or a Member's Bill) appears to be inconsistent with the Bill of Rights. The practice which has emerged in respect of section 7 is that no report to Parliament is made unless a proposal unjustifiably trenches upon rights and freedoms. Conversely if a proposal involves a prima facie infringement of a right, yet it is determined that the proposal amounts to a reasonable and justifiable limitation upon that right, no inconsistency exists for the purpose of section 7 , and significantly, therefore, no report need be tabled in Parliament in relation to the matter. Importantly, such positive vets are not generally made available. This practice needs revisiting. Transparency is essential to the integrity of the section 7 process. In my view, all vetting reports whether positive or negative should be made available to the public. Indeed, such a disclosure policy would be potentially beneficial to the interpretative process and to the work of Select Committees.

\section{THE TWIN PURPOSES OF THE BILL OF RIGHTS}

According to the Long Title, the Bill of Rights has two major purposes. They are:

(a) To affirm, protect, and promote human rights and fundamental freedoms in New Zealand; and

(b) To affirm New Zealand's commitment to the International Covenant on Civil and Political Rights.

These purposes are, however, to be achieved within the paradigm of parliamentary sovereignty, as section 4 makes clear. At this stage, I do not propose to say anything more about these twin purposes, except to note them and to signal that I shall return to them at a later point in this lecture.

\section{RETHINKING SECTION 4 OF THE BILL OF RIGHTS}

In terms of rethinking section 4 the relevant sections of the Bill of Rights are sections 4 , 5 and 6. These state: ${ }^{7}$

4. Other enactments not affected-No court shall, in relation to any enactment (whether passed or made before or after the commencement of this Bill of Rights), -

7 A copy of these sections was supplied to members of the audience. 
(a) Hold any provision of the enactment to be impliedly repealed or revoked, or to be in any way invalid or ineffective; or

(b) Decline to apply any provision of the enactment-

by reason only that the provision is inconsistent with any provision of this Bill of Rights.

5. Justified limitations -Subject to section 4 of this Bill of Rights, the rights and freedoms contained in this Bill of Rights may be subject only to such reasonable limits prescribed by law as can be demonstrably justified in a free and democratic society.

6. Interpretation consistent with Bill of Rights to be preferred -Wherever an enactment can be given a meaning that is consistent with the rights and freedoms contained in this Bill of Rights, that meaning shall be preferred to any other meaning.

\section{A The Problems Created by Section 4}

Since the title of this lecture is "Strengthening the Bill of Rights", it seems only appropriate to consider the weaknesses of the Bill of Rights first in order to convince you of the need for change. At the outset, I want to emphasise that in this talk I am taking it as a given that at present there is still no desire to move towards an entrenched, supreme law-style Bill of Rights and that parliamentary sovereignty is still to be regarded as the most fundamental principle of our constitutional system. ${ }^{8}$ Even working within those parameters, it seems to me that our current Bill of Rights suffers a number of weaknesses which need to be remedied and which can be remedied in a manner which is compatible with preservation of parliamentary sovereignty. I will outline the weaknesses associated with the current section 4 in a general way; those interested in a more detailed account can find one in my recent article in the Oxford Journal of Legal Studies. ${ }^{9}$

Briefly, the problems which are associated with the structure of the New Zealand Bill of Rights Act 1990 are that:

- It is not user-friendly.

- There is a minimal role for Parliament to assert its sovereignty.

- It creates a Janus-like role for the courts.

8 The original proposal contained in the 1985 A Bill of Rights for New Zealand: A White Paper (Government Printer, Wellington, 1985) was for an entrenched supreme-law Bill of Rights. Enquiries conducted by the Justice and Law Reform Select Committee indicated opposition to a transfer of ultimate power from Parliament to the judges: see Final Report of the Justice and Law Reform Committee on a White Paper on a Bill of Rights for New Zealand (1988) AJHR 1 8C.

9 A S Butler "The Bill of Rights Debate: Why the New Zealand Bill of Rights Act 1990 is a Bad Model for Britain" (1997) 17 OJLS 323. 
- It represents an unduly weak fulfillment of our international human rights obligations.

In my view section 4 is the cause of each of these problems.

\section{User-unfriendly}

Looking at the first of those points, our Bill of Rights suffers a lack of user-friendliness in a number of ways.

First, there is the relationship between sections 4 and 6 of the Bill of Rights. That relationship is, in essence, centrifugal. On the one hand, section 6 operates on the principle of the malleability of language and encourages the courts to exploit that feature. On the other hand, section 4 works from the premise that enactments have particular meanings and that the Bill of Rights should not be used to impliedly repeal, invalidate, render ineffective, or disapply those meanings. In short, the two sections pull in separate, indeed often opposing, directions. This point is accentuated by a consideration of the marginal notes to the two sections - that of section 4 informs us that "other enactments [are] not affected", while the marginal note to section 6 tells us "interpretation [of an enactment] consistent with the Bill of Rights to be preferred" which is clearly predicated upon the assumption that the Bill of Rights can and does affect other enactments! The two sections really do make an odd couple!

Next, this centrifugal relationship is exacerbated by a high level of arbitrariness - after all, neither section 4 nor section 6 provide any criteria whatsoever to indicate when one should prefer section 4 to section 6 (and vice versa). The result is that in many cases where there is a true contest between sections 4 and 6 , the outcome will be determined to a very significant degree by the outlook of particular judges.

A good example of both these problems is Flickinger $v$ Crown Colony of Hong Kong. ${ }^{10}$ There, the appellant had been committed to prison to await his return to Hong Kong on commercial fraud charges. An appeal to the High Court was unsuccessful as was an application for habeas corpus before the same Court. The appellant sought to appeal to the Court of Appeal against the decision of the High Court not to release him upon his habeas corpus application. However, according to caselaw stretching back more than 100 years, no such right of appeal existed under the relevant statute; the Judicature Act 1908. In fact, section 66 of the 1908 Act had been consistently interpreted as giving no right of appeal in criminal (as opposed to civil) matters.

10 Flickinger $v$ Crown Colony of Hong Kong [1991] 1 NZLR 439 (CA). 
Despite all this, the Court of Appeal indicated that a right of appeal in criminal matters might well be implied out of section 23(1)(c) of the Bill of Rights, ${ }^{11}$ and if so, that it would be prepared to re-interpret section 66 of the 1908 Act so that it would be no bar to the exercise of such a right of appeal. The Court noted that section 66 of the 1908 Act was apt to be read in the manner advanced by the appellant: no words of that section explicitly barred the right to appeal in criminal habeas corpus matters. Thus, the wording of the statute provided sufficient leeway for, and section 6 of the Bill of Rights required, an interpretation consistent with the Bill of Rights.

But one can legitimately question the compatibility of such an approach with section 4 of the Bill of Rights. After all, the Bill of Rights-consistent interpretation of section 66 of the 1908 Act had consistently been rejected over 100 years and had as recently as 1985 been regarded as "plainly untenable [and] altogether inconsistent with statutory patterns and New Zealand legal history". ${ }^{12}$ Surely, by departing from the case law associated with section 66, the Court of Appeal was not merely engaging in an exercise of "reinterpretation", but rather substituting a new section 66 contrary to section 4 of the Bill of Rights? But if section 6 of the Bill of Rights does not enable this, why is it there?

Moreover, noticeably absent from the judgment are any criteria indicating the circumstances in which section 6 will be preferred to section 4 and later cases have never been able to articulate such criteria. The result? Arbitrariness. Whether section 6 will be relied upon, or section 4 , depends on who the judge is. That is a most unsatisfactory state of affairs.

Equally the relationship between sections 4 and 5 of the Bill of Rights is difficult and unclear. This is particularly so because section 5 is explicitly "subject to section 4 ". So, notwithstanding that section 5 tells us that the rights and freedoms set out in the Bill of Rights are only to be subjected to reasonable and justifiable limits, section 4 tells us the opposite-that unjustifiable limitations can be imposed on rights and freedoms by enactments and that these must be upheld.

Next, that difficult interrelationship skews the natural allocation of tasks under a Bill of Rights. More particularly, because section 5 is subject to section 4, there is good reason for Crown counsel to exaggerate the ambit of an enactment in order to make it appear to be inconsistent with the Bill of Rights. The result of this, of course, is that the citizen who is

11 Section 23(1)(c) reads: "23. Rights of persons arrested or detained - (1) Everyone who is arrested or who is detained under any enactment-... (c) Shall have the right to have the validity of the arrest or detention determined without delay by way of habeas corpus and to be released if the arrest or detention is not lawful."

$12 R v$ Clarke [1985] 2 NZLR 212, 214 (CA). 
seeking to persuade the court to give effect to his or her Bill of Rights rights must demonstrate that there is in fact an interpretation of the enactment which is consistent with the Bill of Rights yet which is reasonable and justifiable in the circumstances.

Furthermore, by making section 5 subject to section 4 , the courts inevitably give inadequate consideration to section 5 . In particular, where a judge is set on upholding the Crown interpretation of a statute, he or she does so normally upon the basis of section 4 . It is clearly the easier path to pursue. Few judges are prepared to go through the hoops required by section 5 (proportionality, minimal interference with rights, rational connection test, and so on). ${ }^{13}$ This is very unfortunate, as many statutes are capable of being justified as reasonable limits on rights and freedoms. Moreover, in those few cases where the courts have actually engaged in a section 5 analysis, usually that analysis has been cursory. The Crown, simply put, is not required to run the gauntlet under section 5 . The result is that one of the aims of a Bill of Rights - creating a culture of justification - is not achieved.

Finally, the relationship between sections 5 and 6 is most unsatisfactory. Section 5 allows reasonable limitations to be put on the rights and freedoms contained in the Bill of Rights. Section 6 mandates the courts to prefer an interpretation or a statute consistent with the Bill of Rights. Which of these comes first? If a statutory limit on a right of freedom is held to be unreasonable under section 5 , is it open to the courts to rely on section 6 thereafter in order to give a meaning to the provision which, while breaching section 5, would impair the right in question to a lesser extent than the interpretation favoured by the Crown, or does section 6 come before section 5, with the result that section 6 has no role as the language of the statute precludes finding a reasonable limitation on the right? The Bill of Rights Act provides no answer and the issue has created quite some confusion for the judges who have had to consider it.

Putting its user-unfriendliness to one side, there are other serious weaknesses in our current Bill of Rights structure.

\section{Parliament's limited role}

While the whole rationale for the current structure of our Bill of Rights is to protect parliamentary sovereignty, in fact Parliament as a body has little or no say in whether it has asserted its sovereignty at the expense of human rights norms. For, as Gault J succinctly remarked in Noort's case, because of sections 4 and 6 the essence of the exercise under the Bill of Rights, "is no more and no less than an exercise in statutory

13 These are the sorts of considerations required by s 5 as found by Richardson J in Noort $v$ MOT; Curran v Police [1992] 3 NZLR 260, 283-4 (CA) and applied in a number of subsequent cases. 
interpretation". ${ }^{14}$ Of course, in undertaking that exercise the judiciary will have regard to the wording and policy of a statute and thus parliamentary activity will have some role to play. But ultimately Parliament's role is minor, for in the end the issue is decided upon arguments as to the meaning of words. And those arguments are made before, and decided by, the judges, not Parliament.

\section{The Janus-like posture of the courts}

Next, the current Bill of Rights creates a difficult Janus-like role for the courts. On the one hand, section 4 of the Bill of Rights tells the courts that Parliament requires them to guard other enactments, protecting them from any ineffectiveness and/or repeal. On the other hand, section 6 instructs the courts to give human rights norms priority whenever possible, suggesting in other words that the courts are the guardians of those norms. This dual role means that the courts are required to look in two different directions simultaneously - the classic Janus-like posture! As a result the courts occupy a most uncomfortable position. The structure of the Bill of Rights exposes the judges to accusations that the imperative of preserving parliamentary sovereignty has been sacrificed at the expense of human rights norms (and vice versa) exposing their decisions to easily-made accusations of illegitimacy. In my view, to expect the judges to act as both the guardians of parliamentary sovereignty and human rights is to require of them a near impossible task. The better alternative is to make the judges the guardians of one or the other. This would at least preserve the legitimacy of their adjudicative function.

\section{International obligations}

As noted earlier, one of the twin purposes of the Bill of Rights is to affirm New Zealand's commitment to the International Covenant on Civil and Political Rights (ICCPR). The current structure of our Bill of Rights results in a dramatic under-fulfilment of our international human rights obligations. Under article 2.3 of the ICCPR, New Zealand has undertaken to provide "effective remedies" in respect of human rights violations. While originally this article was not understood as requiring a State to have in place a supreme law Bill of Rights, the opinions of the Human Rights Committee on this issue have developed to such a stage that it is now clear that in the absence of other comparable non-judicial mechanisms (none such exist in New Zealand) the lack of a judicially enforceable, supreme law Bill of Rights means that the obligations under article 2.3 are not being met. ${ }^{15}$ Indeed, in commenting upon New Zealand's last periodic report,

14 Noort above n 13, 294

15 Note the recent Privy Council judgment in Matadeen v Point [1999] AC 98, 116, holding in effect that the ICCCPR does not require a supreme law bill of rights, but just that "The legal and political system as a whole ... must comply with the Covenant". 
the Human Rights Committee noted, and trenchantly criticised, the subordination of the Bill of Rights to all other statutes. ${ }^{16}$ Of course, it is no wonder that our Bill of Rights drew the wrath of the Human Rights Committee members-it provides a total, blanket protection for all enactments from judicial invalidation. There is nothing "targeted" about our section 4. Rather, it is a blunt instrument which protects both deliberate and unconscious statutory incursions on our rights and freedoms. Accepting as I do, that parliamentary sovereignty is to remain one of our fundamental constitutional principles in the foreseeable future, it seems to me that we must search for some mechanism which enables that sovereignty to be asserted in appropriate cases, yet which ensures as close to near-total compliance with article 2.3 of the ICCPR as possible. Section 4 is not that mechanism.

\section{B Possible Alternatives}

Bearing in mind our time constraints, I will consider two possible alternatives to the current Bill of Rights structure: The United Kingdom Human Rights Act 1998 and the Canadian Charter of Rights and Freedoms 1982.

\section{UK Human Rights Act $1998^{17}$}

The object of the UK Human Rights Act 1998 is to incorporate the European Convention on Human Rights into UK domestic law. However, in achieving that particular purpose, the Labour Government was keen not to do away with the principle of parliamentary sovereignty. ${ }^{18}$ Having had regard to the experience of a number of other jurisdictions, including New Zealand, the Government devised a scheme not dissimilar in fundamentals to the New Zealand Bill of Rights Act, though supplemented by a number of additional features which appear to give the UK Act more teeth than ours.

Comparison reveals the following. First, section 3 of the UK Act is in terms very similar to our section 6 . Second, while there is no provision directly corresponding to our section 4, section 4(6) of the UK Act achieves a similar purpose. The bulk of section 4 of the UK Act provides a mechanism through which the courts are empowered to make a declaration that a provision of primary or secondary legislation is incompatible with a right guaranteed by the European Convention (referred to as a "Convention right").

16 See the criticisms and comments of Messrs Prado Vallejo, El-Shafei, Lallah, Klein and Mrs Evatt recorded at $\mathrm{HR} / \mathrm{CT} / 393$, at 9 and 11 and $\mathrm{HR} / \mathrm{CT} / 395$, at 8,9 and 8 respectively and the final comments of the Committee recording its "regret" that the Bill of Rights was subordinate to all other legislation, recorded at A/50/40, paras 176 and 185 .

17 C. 42

18 See the White Paper, Bringing Rights Home (Her Majesty's Stationery Office, London, 1997) para 2.13 . 
However, section 4(6) makes it clear that such a "declaration of incompatibility" "does not effect the validity, continuing operation or enforcement of the provision in respect of which it is given". Thus, the ultimate subordination of the Human Rights Act to all other legislation is secured. Third, section 19 of the UK Act requires a minister to certify that a particular legislative proposal does not breach the European Convention or, alternatively, to certify that it does so breach but that the government has decided nonetheless to proceed with the proposal. This provision mirrors our section 7 .

The significant innovations in the UK measure are (1) the explicit recognition of the possibility of obtaining a declaration of incompatibility (section 4); and (2) the empowering of a minister to repeal, modify or otherwise take appropriate "remedial action" in respect of legislation which has been declared to be incompatible with the European Convention either by the domestic courts or by the European Court of Human Rights (section 10 read together with the Second Schedule). ${ }^{19}$ The procedure can be invoked by a Minister if he or she "considers that there are compelling reasons" (undefined) for proceeding under section 10. The procedure does require parliamentary approval of a draft remedial order (unless the Minister certifies that urgency is so necessary that no such approval should be required). ${ }^{20}$

Turning first to the declaration of incompatibility, there are a number of advantages to this mechanism. First, because a declaration of incompatibility has a statutory authorisation, a citizen has a right to go to court to ask for a declaration that even the clearest of human rights violations by a statute is exactly that-a violation. This means that what would be regarded in New Zealand as a "no-hoper" case is, in the United Kingdom, a legitimate action. This has important ramifications for such practical issues as legal aid. Second, the mechanism means that much of the difficult interplay between sections 4 and 6 which we experience in New Zealand is avoided. Because a litigant can seek a declaration of incompatibility, the courts must undertake a proper assessment of the reasonableness of any limitation upon a citizen's Convention rights. Equally, assuming that the Crown does not wish to have a declaration of incompatibility registered against it, the Crown must undertake its proper task of seeking to advance good reasons in support of the particular statutory encroachment on Convention rights to demonstrate their reasonableness. There will be little attraction in exaggerating the true scope of a particular statutory provision in order to avoid the application of the European Convention, particularly if the declaration of incompatibility were to lead to subsequent ministerial

19 The remedial order power can even be exercised in respect of related legislation which has not been declared incompatible; Schedule 2, s 1(2)(a).

20 Schedule 2, s 2. But see Schedule 2, s 4 which puts in place extra requirements in respect of urgent orders. 
"remedial action" being taken. Third, the declaration of incompatibility provides a useful avenue through which the attention of Parliament can be drawn to rights violations by affected citizens. And because there will have been a proper deliberation on issues such as justified limitations, a conclusion of incompatibility by a court will have the mana of being regarded as a considered decision; there is consequently a good chance that Parliament will take heed of such a decision. This contrasts markedly with the quite inadequate practice of the courts under our Bill of Rights discussed above. Fourth, the structure ensures that the courts are not left in a difficult Janus-like position: while ultimately Parliament has excluded the possibility of invalidation, nonetheless the structure of the Human Rights Act makes it clear that the primary role of the courts is to act as guardians of human rights.

Before moving on, I should note that it has been suggested by some commentators that similar declarations of incompatibility might be obtained under our Bill of Rights. ${ }^{21}$ The suggestion was first made by Professor Jock Brookfield. ${ }^{22}$ The argument is that section 4 of the Bill of Rights only prevents the courts from doing a limited number of things in relation to enactments: impliedly repeal or revoke them, invalidate them, hold them to be ineffective, or decline to apply them. By implication, a court is free to do anything else in relation to enactments (an application of the Latin maxim expressio unius, exclusio alterius). One such possibility is to make a positive finding of unjustified inconsistency between an enactment and the Bill of Rights, in other words a declaration of incompatibility.

I would support such a development. It would further the goal of promoting fundamental rights and freedoms set out in the Long Title to the Bill of Rights by drawing Parliament's attention to conflicts between the Bill of Rights and protected rights. At the same time, such a declaration would not undermine parliamentary sovereignty. The whole notion of the declaration is premissed upon that sovereignty. Indeed, in light of the fact that Parliament clearly wants to be informed of rights problems in relation to post1990 legislation (the section 7 mechanism makes this clear) it can well be argued that Parliament would welcome judicial pronouncements on the consistency of both post- and pre-1990 legislation. Such a move need not be seen as a gratuitous criticism of Parliament

21 The following two paragraphs contain more expanded remarks than in the original lecture, on the possibility of declarations of incompatibility in New Zealand, and reflect views expressed in answer to a question from the floor at the end of the lecture. After this lecture, the Court of Appeal has appeared to indicate that it will move in the direction of making judicial declarations of inconsistency with the Bill of Rights: Moonen $v$ Film \& Literature Board of Review (1999) 5 HRNZ 224 (CA).

22 J Brookfield "Constitutional Law" [1992] NZ Recent Law Review 236. 
by the judiciary, ${ }^{23}$ but as authoritative assistance on difficult issues of law and freedom designed to ensure that Parliament is fully informed as to how best the twin purposes of the Bill of Rights can be better met.

If such a declaration procedure is to be developed it would have to be sourced in the Bill of Rights itself - a declaration of inconsistency could not be sought under the Declaratory Judgments Act 1908. The 1908 Act only envisages proceedings which challenge legislation on the ground of the manner of its enactment, rather than the validity of its content. ${ }^{24}$ A finding of inconsistency with the Bill of Rights is not a finding of unlawfulness as such: the inconsistent enactment is valid notwithstanding the inconsistency. The possibility of a move towards such declarations of incompatibility is discernible in the recent same-sex marriage case, Quilter $v$ Attorney-General. ${ }^{25}$ In that case, Thomas J commented that where a judge discovers an inconsistency between the Bill of Rights and another enactment, he or she would not be doing his or her duty if he or she failed to "proclaim" such an inconsistency. ${ }^{26}$ One final comment. If the judges do move in this direction, in my view, a decision to make a declaration should be non-discretionary: if the "remedy" is legitimately ${ }^{27}$ sought and the inconsistency found, the declaration should be made.

Turning next to the "remedial action" procedure in the UK Human Rights Act, there are a number of positive features. Section 10 provides a relatively quick means by which statutory interferences with Convention rights can be remedied where a declaration of incompatibility has been obtained or a negative ruling has been made by the Strasbourg Court. In the slow-moving parliamentary timetable at Westminster this is a real advantage. Next, the powers given to the Minister by section 10 to achieve compliance with the European Convention are extremely ample (retrospective application, total repeal possible, modification/amendments possible, power to stipulate class of beneficiaries of "remedial action") and should encourage Ministers to use the powers without fear of having to go overboard, nor of not being able to do enough.

23 See a comment made by Cooke P in Temese v Police (1992) 9 CRNZ 425, 427 (CA) in noting Professor Brookfield's suggestion. It should be noted though that Cooke P went on to say that such a price might well have to be paid.

27 By "legitimately", I mean that the plaintiff has standing, the inconsistency is raised upon and relevant to the pleaded facts, and is squarely sought as "relief" in an appropriate manner. 
Nevertheless there are a number of patent disadvantages to the UK scheme. Principally, like section 4 of our Bill of Rights, the UK scheme suffers from overbreadth. In particular, like our section 4 , the UK scheme provides a total, blanket protection to all statutes from invalidation. In turn, this means that both deliberate and unconscious violations of human rights are immune from invalidation. The result is that in relation to many unreasonable and unjustifiable statutory interferences with human rights, there will be no effective remedy available. Certainly, the UK scheme is an improvement, because successfully obtaining a declaration of incompatibility may provide a springboard towards activating ministerial "remedial action" under section 10 of the UK Act. However, the "remedial action" procedure is, at the end of the day, a political process not a legal one. There is no guarantee that, having obtained a declaration of incompatibility, any ministerial remedial action will be taken to redress the rights violation. Thus, in law and reality, whether a citizen is to continue to suffer a statutory incursion on his or her rights is left to the vagaries of the political process. ${ }^{28}$ In consequence, the UK section 10 mechanism is not an effective remedy for the purposes of article 2.3 of the ICCPR. Moreover, it appears to me at least to be somewhat incongruous that a Bill of Rights which resists giving a power of invalidation to judges, because of a desire to preserve Parliamentary sovereignty, nonetheless gives wide powers to the executive to overturn statutes (albeit with a general requirement of approval by Parliamentary resolution) - that is an odd way of preserving parliamentary sovereignty.

\section{Canadian Charter of Rights and Freedoms 1982}

Many commentators in New Zealand work on the assumption that the Canadian Charter of Rights is an entrenched, supreme law-style Bill of Rights. While it is indeed true that the Canadian Charter is entrenched (see Part V of the Constitution Act 1982), much of the Canadian Charter is not actually supreme law. This is because according to section 33(1) of the Charter, "Parliament or the legislature of a province may expressly declare in an Act of Parliament or of the legislature, as the case may be, that the Act or a provision thereof shall operate notwithstanding a provision included in section 2 or sections 7 to 15 of this Charter." Where such an express declaration has been made, the legislation operates with full force and effect notwithstanding any relevant Charter provision. A "notwithstanding" declaration operates for a maximum of 5 years, renewable indefinitely (see sections $33(4),(5)) .{ }^{29}$

28 In fairness, the White Paper, above n 18 para 2.10, records that "A declaration that legislation is incompatible with the Convention rights ... will almost certainly prompt the Government and Parliament to change the law".

29 A copy of s 33 of the Canadian Charter was supplied to members of the audience. 
It will be readily apparent that the purpose of section 33 is to preserve, as against many of the more potent provisions of the Canadian Charter, the sovereignty of parliament. To my mind, the Canadian Charter "notwithstanding" model offers a number of distinct advantages over our current Bill of Rights and the model found in the UK Human Rights Act 1998.

First, the Canadian Charter model is user-friendly. The problems identified earlier in relation to the operation of our sections 4, 5 and 6 do not arise. Section 33 of the Charter does not skew the way in which arguments are run. Under the Charter, the citizen bears the onus of demonstrating a prima facie infringement of his or her rights. Once such an infringement is established, the Crown must show that the relevant legislation amounts to a reasonable limitation upon the rights affected (see section 1 of the Canadian Charter). There is no tactical advantage to the Crown to exaggerate the scope of legislation; nor does the citizen-challenger have to undertake the Crown's job and argue for reasonable interpretations of the relevant legislation. Equally, the judges occupy a more comfortable position under the Canadian Charter. Whether Parliament has sought to exercise its sovereignty is easily verified - does the statute contain a declaration in terms of section 33 ? If yes, then the courts are required to defer to the terms of that declaration (assuming there are no procedural difficulties); if no, the judges move to the substantive rights and limitation issues unconstrained by concerns about trenching on Parliament's legislative supremacy. The mental gymnastics required by our sections 4 and 6 do not arise.

Second, the section 33 procedure achieves the important goal of ensuring that any decision to unjustifiably trench upon human rights by Parliament is done with full political responsibility and in full awareness of the effects of the legislation. At the same time, however, section 33 provides a simple and straightforward mechanism through which Parliament's sovereignty can be asserted. The majority required is a simple majority; and the assertion must only be express as to which provision or provisions of the Charter are intended to be ousted. Moreover, the mechanism leaves little discretion in the hands of judges and provides them with few opportunities to frustrate the exercise of Parliament's legislative supremacy.

Third, the Canadian courts are not left in the awkward Janus-like posture of their New Zealand counterparts. Section 33 of the Charter establishes that the primary guardians of parliamentary sovereignty are the federal and provincial legislatures themselves. Conversely, the primary role of the judges under the Charter is to act as the guardians of human rights norms. While, of course, the courts will still be exposed to substantive criticism in respect of decisions they make on the scope of rights and on the acceptability of governmental limitations on those rights, the extra tension involved in the unhappy relationship between sections 4 and 6 of the New Zealand Bill of Rights is avoided. 
Finally, while the section 33 mechanism means that there may be some statutes which are clothed with an immunity from invalidation in the case of inconsistency with human rights norms, nonetheless (assuming that Parliament does not over-indulge its use of the notwithstanding declaration) by far the greater majority of statutes are vulnerable to fullscale judicial review. As a result, therefore, in respect of almost the entire Canadian statute books (both federal and provincial), a Canadian citizen has access to an "effective remedy" in terms of article 2.3 of the ICCPR. Adoption of a section 33-like provision in New Zealand would mean that the Human Rights Committee's consistent criticisms of New Zealand's continued immunisation of statute law from invalidation on grounds of inconsistency with human rights norms would largely dissipate.

But is the Canadian model really parliamentary sovereignty? In my view, the answer to this question must be an emphatic Yes.

Elsewhere I have expressed the view that "parliamentary sovereignty is the principle that Parliament is the apex of the constitutional structure: It is the source of supreme law and has ultimate power to determine what will and what will not be law."30 Consistent with this principle, Parliament may choose to declare that it is content to subject all of its enactments to judicial scrutiny, but reserve to itself (through an act of a simple majority of its membership) the power to preempt or overturn any judicial decision to invalidate a statute. For those of you uncomfortable with the word "invalidation", substitute the word "disapplication" and the same affect is achieved - as between applying the norms set out in the human rights statute (that is the Bill of Rights Act) and another, conflicting statute, the court is required to apply the former, rather than the latter, at the behest of parliamentary direction. Parliament telling the courts what to do with its statutes - that surely is real parliamentary sovereignty at work.

Adoption of an unentrenched ${ }^{31}$ version of the Canadian Charter "notwithstanding" mechanism would not be a radical departure from a proper understanding of the principle of parliamentary sovereignty as illustrated by overseas law.

In the United Kingdom it now appears to be settled law that section 2(4) of the European Communities Act 1972 (through which European Union law has effect domestically in the United Kingdom) means that all United Kingdom legislation which is inconsistent with European law is impliedly repealed and not to be applied, subject to the

30 Butler, above n 9, 340.

31 The importance of the measure being unentrenched is that that status means that a later Parliament is free to amend or repeal the Bill of Rights as it sees fit-if it could not do so this would be a fetter upon parliamentary sovereignty according to one of the dominant schools of New Zealand (and UK) constitutional thought. 
power of Parliament to exercise its sovereignty and override any European law with which it expressly disagrees. ${ }^{32}$

A similar approach is evident in the Canadian Supreme Court decision in Re Winnipeg School Division (No 1) and Craton. ${ }^{33}$ In that case, there was a conflict between the provisions of the Manitoba Public Schools Act 1980 (which explicitly permitted school divisions to adopt and apply a mandatory retirement-at-age-65 policy) and Manitoba's Human Rights Act 1974 (which expressly prohibited employers from discriminating on grounds of age). Traditional common law principle would suggest that the 1980 Act repealed the 1974 Act because (1) a later Act repeals an earlier Act (the doctrine of implied repeal); and (2) the principle of generalia non specialibus derogant (that is the general does not derogate from the specific) would apply. However, a unanimous Supreme Court of Canada preferred to give effect to the Human Rights Act over the Public Schools Act. At the outset, the Supreme Court acknowledged that its task was to give effect to the intention of the Manitoba legislature. In so doing, however, the Court made certain assumptions as to the intentions of that legislature. In an important passage, McIntyre J stated: ${ }^{34}$

Human rights legislation is of a special nature and declares public policy regarding matters of general concern. It is not constitutional in nature in the sense that it may not be altered, amended, or repealed by the Legislature. It is however of such nature that it may not be altered, amended, or repealed nor may exceptions be made to its provisions save by clear legislative pronouncement. To adopt and apply any theory of implied repeal by later statutory enactment to legislation of this kind would be to rob it of its special nature and give scant protection to the rights it proclaims.

It is worth re-emphasising that the Supreme Court in Craton's case did not "invalidate" the Public Schools Act 1980; after all, that Act was not ultra vires the power of the provincial legislature. However, what the Court did do was to say that where it was confronted with a conflict between human rights legislation and another enactment, absent an express declaration of an intention to override the human rights legislation, the Court would work on the assumption that the best way of giving effect to the legislature's overall intention was to ignore/disapply the human rights-incompatible provision. As will be apparent such a ruling in no way impairs the sovereignty of the Manitoba legislature - it could, if it wished, reverse the rule of interpretation adopted by the Supreme Court on a general basis, or in appropriate cases reverse the specific ruling. The upshot is that human

32 Butler, above n 9, 340.

33 Re Winnipeg School Division (No 1) and Craton (1985) 21 DLR (4th) 1 (SCC).

34 Re Winnipeg School Division (No 1) and Craton above n 33, 6. 
rights norms override inconsistent statutes, all within the parliamentary sovereignty paradigm.

\section{MAKING THE SECTION 7 REPORTING PROCESS MORE TRANSPARENT}

Let us move now to section 7 of the Bill of Rights. ${ }^{35}$

Section 7 of the Bill of Rights requires the Attorney-General to bring to the attention of the House of Representatives any provision of a Bill that "appears to be inconsistent with any of the rights and freedoms contained in this Bill of Rights". Section 7 provides for a form of non-curial vetting of proposed legislation. Section 7 resulted from a recommendation of the Justice and Law Reform Select Committee which considered the draft Bill of Rights. The committee felt that if the Bill of Rights had a prophylactic effect on new legislation, this would compensate in part for the subordination of the Bill of Rights to all other legislation. Because all proposed legislative measures must pass muster under the Bill of Rights, or else receive the unwanted attention of an Attorney-General's section 7 report, section 7 has ensured that the Bill of Rights is a significant factor in the policy formulation and the law drafting processes.

Having now had the privilege to work in the Bill of Rights team at the Crown Law Office for some two months or so, I am of the view that section 7 does have teeth and can provide a useful mechanism through which respect for the principles of the Bill of Rights can be realised. Indeed, practice indicates that often Bill of Rights inconsistencies which appear in draft Bills can be readily solved over the phone, once the problem has been pointed out. At the same time, however, there are weaknesses in the current process which need addressing. In particular, there is a substantial lack of transparency in the process, which means that you, rather than having the evidence which would convince you that the section 7 process actually works, must rely on assurances from people like me working within the process. While I am sure you trust me(!), the point is you should not have to.

The problem is that while the public are able to have access to negative vets of legislation, ${ }^{36}$ so-called "positive vets" are not generally available. In the early life of the

35 See generally P Fitzgerald "Section 7 of the New Zealand Bill of Rights 1990: A Very Practical Power or a Well-Intentioned Nonsense" (1992) 22 VUWLR 135; G Huscroft "The AttorneyGeneral, the Bill of Rights, and the Public Interest" in Huscroft and Rishworth, above n 1; J McGrath "The Bill of Rights and the Legislative Process" in The New Zealand Bill of Rights Act 1990 (Legal Research Foundation, Auckland, 1992) 98.

36 Where the Attorney-General is of the view that a proposed Bill is inconsistent with the Bill of Rights, Parliamentary Standing Orders require that a substantial report be tabled before the House of Representatives outlining the reasons for this view: Standing Order 260(1). 
Bill of Rights, the Crown Law Office and the Department of Justice (now Ministry of Justice) - the two agencies which are engaged in the Bill of Rights vetting processadopted a policy of refusing access to the documentation surrounding the vetting process. Indeed, the Department of Justice invoked legal professional privilege to protect vetting documentation from disclosure under the Official Information Act 1982, an approach ultimately (and in my view unfortunately) upheld by the Ombudsman. Current practice has altered slightly, in that positive vets and memoranda will now be released on a case by case basis. The new system of selective disclosure, while in one sense an improvement, does raise questions as to the integrity of the system. It could suggest (rightly or wrongly) that not all vets are sufficiently robust as to warrant disclosure and public scrutiny. This is unfortunate. In my view, the issue requires revisiting. The whole purpose of the procedure is to ensure that New Zealanders' human rights are not unjustifiably interfered with. The public has a keen interest in understanding why, in particular instances, the view has been taken that a legislative measure is consistent with the Bill of Rights. That information should be made available to them.

A disclosure of information surrounding individual vetting exercises would not only be an improvement in terms of transparency - making available the vets conducted by the Department of Justice and Crown Law Office staff as a matter of course has the potential to significantly improve the conditions under which these vets are conducted. The glare of publicity will ensure that the process will be immune from any temptation to compromise on human rights principles as part of the consultation process with the responsible department advancing the legislative proposal.

Furthermore, the Bill of Rights has been gradually emerging as a significant feature of submissions made on Bills before parliamentary select committees - the New Zealand Law Society, for example, regularly makes comment on the Bill of Rights-compatibility of legislative proposals. In the absence of access to the positive vet reports prepared for the Attorney-General, the task of submitters is all the more difficult as is the ability of the select committees to assess the merits of the Bill of Rights claims of the submitters. The whole process would surely benefit from an environment of full information.

There is yet another important reason as to why positive vets should be released. Within Government, great credence has been given to the direction in section 6 of the Bill of Rights that enactments be read in a manner consistent with the rights and freedoms guaranteed by the Bill of Rights. This has been especially so in the preparation of section 7 vets. In a good many cases, Bills receive a positive vet only because officials in the Ministry of Justice and the Crown Law Office have anticipated that, notwithstanding its language, the measure will be interpreted by the courts in accordance with the direction in section 6. In turn, this advice is made available to the Attorney-General (usually emphasised in the body of the advice letter tendered to the Attorney) and is the basis of 
the Attorney's advice to Cabinet that the Bill raises no Bill of Rights issues and should proceed. In my view, to the extent that this indicates governmental acceptance of the limitations which the Bill of Rights will probably place upon the reach or operation of legislative language, that advice could well be of value for a court endeavouring to interpret the measure. Indeed, that advice could indicate to counsel and court the possible uses of section 6 in the context of the measure as enacted and could well make the difference in persuading the court to rely on section 6 of the Bill of Rights in preference to section 4 .

A number of possibilities exist as to how positive vets could be made available. Standing Orders could be amended to require or permit the tabling of positive vets in Parliament. Alternatively, positive vets could be posted on the websites of the Ministry of Justice and Crown Law Office, and made available in hard copy form for those who request them.

\section{CONCLUSION}

In conclusion I hope I have done enough to demonstrate some of the weaknesses of the current structure of our Bill of Rights. First, in my view, section 4 should be abandoned and replaced with a provision which mirrors that found in section 33 of the Canadian Charter. Parliamentary sovereignty would be preserved but the twin purposes of the Bill of Rights - the protection, promotion and affirmation of fundamental rights and the affirmation of New Zealand's commitment to the ICCPR - would be given better effect. Second, current practice in relation to the release of positive vets prepared for the purpose of the Attorney-General's section 7 reporting obligations needs revising. The integrity of a generally well-functioning system requires transparency for public and professional confidence to be maintained. Moreover, release of such reports holds out other advantages which should advance the Bill of Rights' twin purposes.

Thank you very much for your kind attention. 